\title{
Success and Applied Tools in Post-Industrial Rehabilitations
}

\author{
Anna Adorján \\ Department of Garden and Open Space Design, Corvinus University of Budapest \\ anna_adorjan@uni-corvinus.hu
}

\begin{abstract}
The problem of brownfields has become an increasingly important issue in Hungary - these urban areas have great potential for reuse, presenting a major challenge for landscape architects.

As a landscape designer and urban planner, in this paper I am trying to answer the question why certain rehabilitated site work better than others, what the strengths of one or the other are. In search of sustainability in brownfield rehabilitations, I am analysing 5 selected post-industrial sites, and compare them with the undergoing rehabilitation of the Ózd Steel Works.
\end{abstract}

Keywords: Brownfields, transformation, reuse, urban landscapes, case study approach

\section{INTRODUCTION}

Brownfield sites present great development opportunities for cities, however, their revitalisation meets significant difficulties [1]. Due to the differences between the sites, the diversity of goals and available tools, it is difficult to formulate guidelines for their reuse that could be applied everywhere. The present paper attempts to do so through the analysis of three Western European and three Hungarian examples. [2]

\section{CASE STUDIES}

\begin{tabular}{|c|c|c|c|c|c|c|c|}
\hline $\begin{array}{l}\text { project } \\
\text { name }\end{array}$ & $\begin{array}{l}\text { area } \\
\text { (ha) }\end{array}$ & $\begin{array}{l}\text { urban } \\
\text { situation }\end{array}$ & $\begin{array}{l}\text { renewal } \\
\text { period }\end{array}$ & $\begin{array}{l}\text { original } \\
\text { function }\end{array}$ & $\begin{array}{l}\text { temporary } \\
\text { function }\end{array}$ & new function & $\begin{array}{l}\text { impact } \\
\text { area }\end{array}$ \\
\hline Zollverein & 100 & peripheral & 2010 & coal mine & - & $\begin{array}{l}\text { culture, education, } \\
\text { commercial, } \\
\text { entertainment, } \\
\text { park }\end{array}$ & Ruhr region \\
\hline Gasometer & 40 & peripheral & 2001 & gas tank & $\begin{array}{l}\text { filming } \\
\text { locations, } \\
\text { exhibition } \\
\text { space }\end{array}$ & $\begin{array}{l}\text { culture, education, } \\
\text { commercial, } \\
\text { accommodation, } \\
\text { residential }\end{array}$ & $\begin{array}{l}\text { Simmering } \\
\text { quarter }\end{array}$ \\
\hline $\begin{array}{l}\text { Haute-Deûle } \\
\text { Banks }\end{array}$ & 25 & central & 2013 & $\begin{array}{l}\text { textile } \\
\text { works }\end{array}$ & - & $\begin{array}{l}\text { commercial, high- } \\
\text { tech industry, } \\
\text { residential, park }\end{array}$ & $\begin{array}{l}\text { Lomme } \\
\text { quarter }\end{array}$ \\
\hline Millenaris Park & 5,3 & central & 2001 & $\begin{array}{l}\text { machine } \\
\text { factory }\end{array}$ & - & culture, park & $\begin{array}{l}\text { whole } \\
\text { Budapest }\end{array}$ \\
\hline $\begin{array}{l}\text { Zsolnay } \\
\text { ículturalQuarter }\end{array}$ & 5 & central & 2011 & $\begin{array}{l}\text { china } \\
\text { factory }\end{array}$ & - & $\begin{array}{l}\text { culture, } \\
\text { education, park }\end{array}$ & $\begin{array}{l}\text { Zsolnay } \\
\text { quarter }\end{array}$ \\
\hline $\begin{array}{l}\text { Ózd Culture } \\
\text { Factory }\end{array}$ & 5,6 & central & 2009 & steel works & - & $\begin{array}{l}\text { culture, } \\
\text { education, park }\end{array}$ & $?$ \\
\hline
\end{tabular}

Table 1. Basic data and specifications of sites 


\subsection{ZOLLVEREIN - Cultural complex, park}

Designers: OMA, Rem Koolhaas, SAANA

The former Zollverein coal mine is located in Essen, North Germany.

Today, the nearly 100 -hectare complex operates as a cultural and leisure center. The designers of the rehabilitation project added some new elements to the existing building stock, but the industrial atmosphere of the original buildings were retained.

Nowadays, the former shafts provide room for cultural and educational functions. In addition, a design museum, restaurants, cafes, lookouts and several other leisure and entertainment facilities await visitors. [3] (Figure 1.)
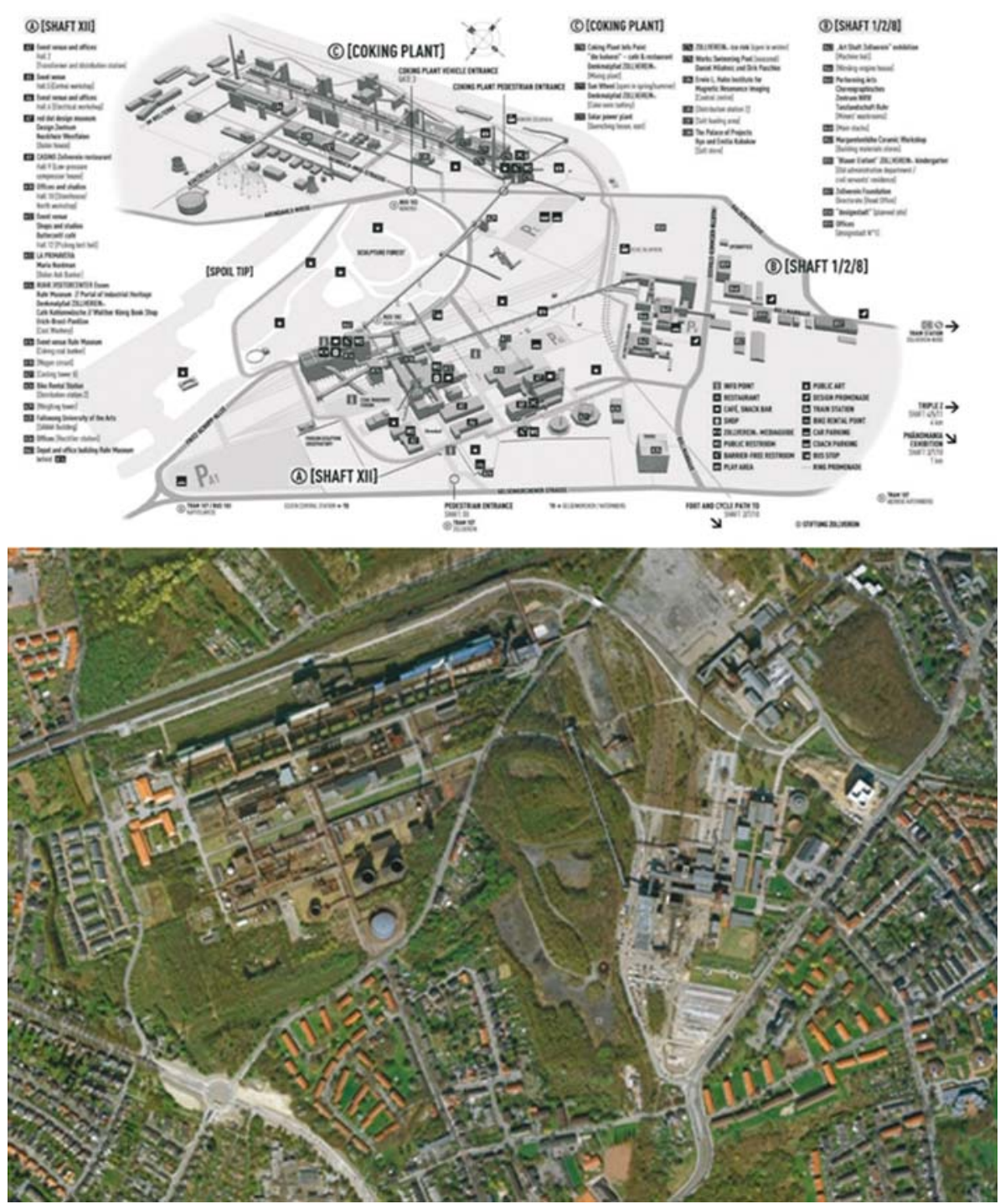

Figure 1. Zollverein Cultural complex, Essen 


\subsection{HAUTE-DEULE Banks, Lille}

Designer: Atelier de Paysages Bruel Delmar-office

The Haute-Deûle canal, flowing through the city of Lille, used to play a very important role in the life of the city. The textile industry had facilities on the banks of the canal, workers' dwellings were built around it and a system irrigation canals also crossed the area. After the industrial production was discontinued, the condition of the buildings and their surroundings began to deteriorate rapidly.

The centrally located channel and the abandoned industrial facilities were not a worthy environment for the nearby residential areas, therefore the municipality decided to launch a rehabilitation project for the area.
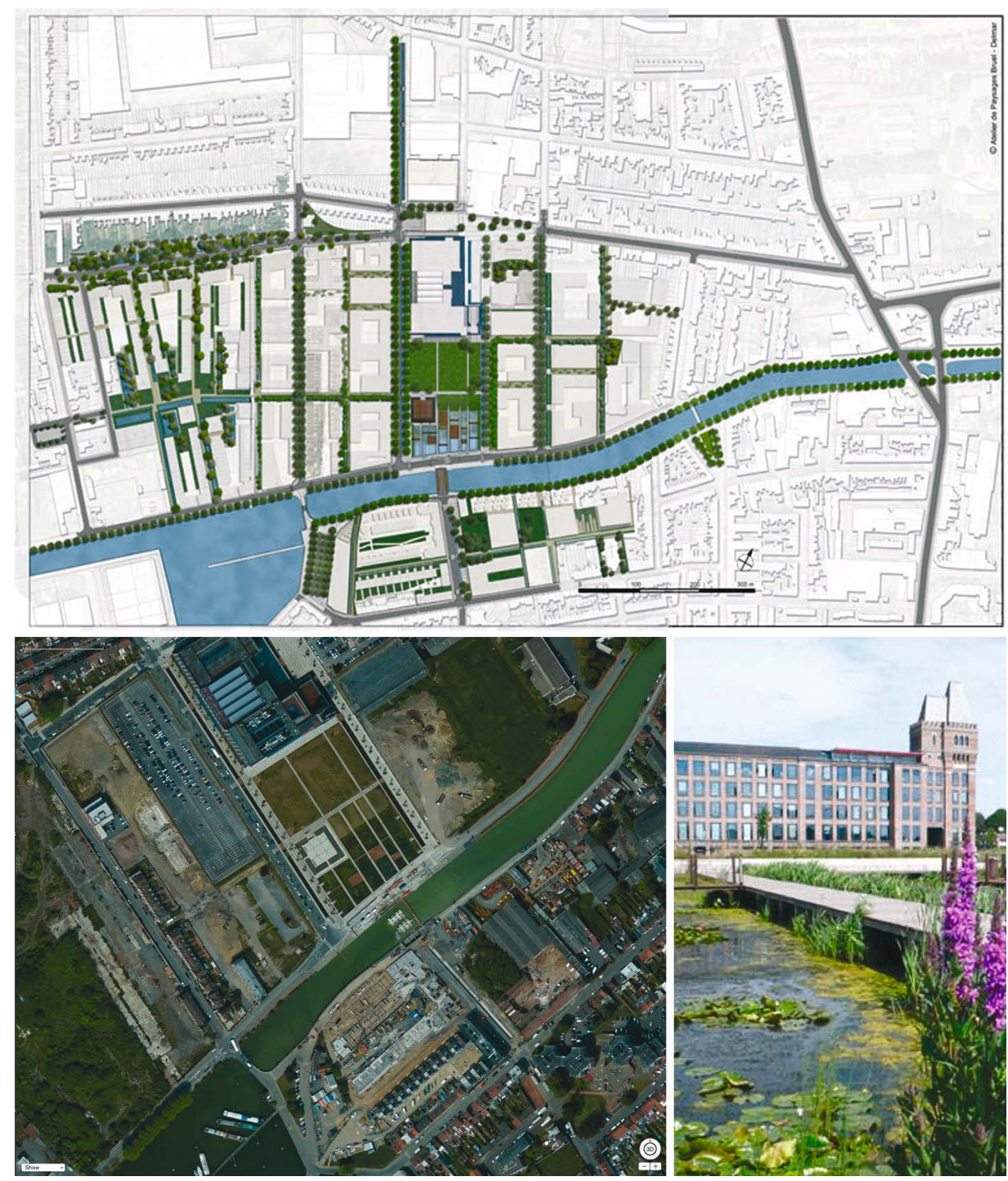

Figure 2. Haute-Deûle Banks, Lille 
The designer team working on the project described it as "a sustainable district surrounding the old textile mill". The design approaches integrate modern technology, aesthetic designs, functionality and the protection of the environment to create a welcoming space.

The project was awarded the Ecological District Prize in 2009, on the theme of 'Water'. It also received the French 2010 Prize for Urban Development Prize. In 2013, it received the National Eco-district Label, awarded by the Ministry of Ecology. [4] (Figure 2.)

\subsection{Millenáris park}

Designers: Wéber Architects, László Benczúr, Ákos Takács, New Direction Group, CÉH Creative Community

Abraham Ganz founded his foundry in Budapest in 1844, close to the historical city centre, and it developed into a major industrial company within a few decades. In the end of the XIX. century they moved to the present site, Lövölde street.

Due to its location close to the center, the relocation of the factory has already been proposed at the beginning of the 20th century. However, the outbreak of World War I prevented this from happening.

The relocation was put forward again in the 1990s, mostly because of the pollution and the increasing value of the area. It was finally carried out with the involvement of foreign capital.


Figure 3. Millenáris Park, Budapest 
The rehabilitation was started in 2000. During the transformation process, the former industrial buildings were turned into public buildings, or spaces with cultural and entertainment functions. The project created a new public park with an impact on the life of the quarter and the whole of Budapest, which serves as a meeting place and recreational area.

From a landscape architectural viewpoint the Millenáris project has an interesting feature; the site is located in a valley and air channel therefore the new park allows fresh, cool air from the surrounding mountains to flow into heart of the city improving the urban climate and contributing to better comfort especially in the summer.

If we look in closer detail to these three studies, we can conclude that $t$ three examples show a sort of integration. In the case of Zollverein the integration of the industrial site and the city is the main point. In the Haute-Deûle project the combination of the former industrial site and the water system is the key, while the Millenáris Park is a successful example for the integration the site as a whole into the urban landscape at large. In all three cases set of new functions have been introduced to support the interventions from an economical point of view. Besides contemporary functions other features have been introduced and included into the plan, like the urban green network, the water system and the urban climate. These ideas are precisely the results of the contribution of landscape architects who were able to add new aspects to the reconstruction of architectural artefacts. (Figure 3.)

\subsection{Gasometer}

Designers: Jean Nouvel, Coop Himmelb(l)au, Wilhelm Holzbauer, Manfred Wehdorn

Located in the Austrian capital, Vienna, near the urban stretch of the A4 motorway and the junction of A4 and A2, Gasometer City is a quarter created from the gas tanks of the former gasworks. The study area is a 4-hectare part of the quarter, specifically the site of the four former gas tanks and their surroundings.

The city of Vienna authorized the construction of the gas storage facilities in 1896, which were put into operation in 1899 . However, the tanks were able to meet the growing urban demands for only a short time, and technology also changed rapidly.

After long discussions, in 1996 a decision was made that the tanks will be reused, with new functions. The motto was to create an opportunity to live, work and spend one's free time under one roof. The architectural plans for the gas tanks were designed by international star architects. [4]

\subsection{Zsolnay Cultural Quarter}

Designers: MCXVI, GEON, s.m.all design studio, Térlabor, ABORA, TAAT, Pécsépterv, Helfrich and Konrád, S73, New Direction group

The ceramic factory, located in Pécs, was founded in 1852 by Miklós Zsolnay, who was followed by his son, Vilmos, who turned it into an internationally famous establishment. The products made here were unique and revolutionary, and won several international awards. The whole family participated in the development of products and the operation of factories, even their houses were built in the area.

In the following decades, the plant changed owners repeatedly, until the former industrial area was developed into a Cultural Quarter in 2010, within the framework of the European Capital of Culture program. 
The buildings in poor condition were demolished, and the rest was renovated and transformed, adding contemporary forms to the industrial-style buildings.

The factory's own park, containing valuable plants and sculpture also reconstructed. The complex renewal of the factory and its surroundings had an impact on the entire city.

\section{DESIGN TOOLS}

The selected projects can all be considered as successful revitalizations in some aspects. In the following assessment, the shared and unique points of action in these projects are taken into account, demonstrating the wide range of tools and options. [5]

\subsection{Shared tools}

- Local social demand and support for the renewal of the site - acceptance of the plans or even involvement and participation in the planning process.

- Economic strength - use of internal resources, local government or local investors investing in the renewal of the area, creating an opportunity to incorporate aspects that are important to them (eg. long-term sustainability and operability, real demands)

- Complex design concept for the renewal - interdisciplinary planning; with regional context taken into account, the impact of the local renewal may spread to other areas the city or the region, increasing the long-term sustainability.

- Elimination of pollution

- Renewal of buildings - preservation of old values by reusing existing buildings and creation of new values by integrating contemporary architecture

- Plantation, revegetation of the sites, increase the proportion of green areas

- New outdoor functions, pedestrian and bike routes, playgrounds or recreation areas,

- Innovation, high-tech buildings, the most advanced technology available or "star architects" -the former (heavy) industry is replaced by today's high-tech industry, innovative elements appear in the projects.

Often the use of innovative solutions becomes necessary when the characteristics of the area do not allow the use of the well-established ones.

If successful, it is unusual and novel. The presence of 'star architects' also contribute to the new image of the area.

- PR and follow-up - unique and attractive image, monitoring, continuous renewal. The key to the survival and long-term success of rehabilitation projects is flexibility and the market-based approach. This can be achieved by the creation of a distinct image and its maintenance by ongoing marketing, and the management of the area. 


\subsection{Unique tools}

Based on the specific features of individual sites, a variety of other tools can also be used, the most commonly used of which are as follows:

- External economic catalysts - EU project financing, State Aid (Zsolnay quarter, Zollverein)

- Involvement of economic operators as investors (Gasometer)

- Creation of numerous jobs (Gasometer)

- Changing the urban situation, infrastructure development: new metro line (Gasometer), pedestrian or bicycle bridges and links (Lille, Zsolnay quarter)

- Utilization of natural features, efforts to increase sustainability (Lille)

- Creation of cultural values (Zsolnay quarter, Millenáris)

- Interpretation of local history (Gasometer, Zsolnay quarter, Zollverein)

- Pre-planning the effects on urban structure and ecology (Gasometer, Lille, Zollverein)

- Temporary utilization and participatory planning (Gasometer)

Naturally, the list of tools can be expanded.

\subsection{Classification of tools}

Successful rehabilitation is economical, with social acceptance and positive social outcomes and has a positive impact on the environment. These three distinct but interrelated goals can be used for the classification of tools (Table 2).

\begin{tabular}{|c|c|}
\hline Goal & Design tools \\
\hline \multicolumn{2}{|l|}{ Economy } \\
\hline \multirow{4}{*}{ Complete utilization } & Complex design concept for the renewal- interdisciplinary planning \\
\hline & Changing the urban situation by infrastructure development \\
\hline & PR and follow-up \\
\hline & Monitoring \\
\hline \multirow{4}{*}{$\begin{array}{l}\text { Self-sufficiency and } \\
\text { generation of income }\end{array}$} & Complex design concept for the renewal - interdisciplinary planning \\
\hline & Creation of jobs \\
\hline & PR and follow-up \\
\hline & Economic strength - use of internal resources \\
\hline \multirow{4}{*}{$\begin{array}{l}\text { Role as engine of } \\
\text { economic growth }\end{array}$} & Economic strength - use of internal resources \\
\hline & Unique and attractive image \\
\hline & Innovation, high-tech buildings, the most advanced technology available or "star architects" \\
\hline & External economic catalysts \\
\hline
\end{tabular}




\begin{tabular}{|c|c|}
\hline \multirow{6}{*}{ 24-hour use } & Changing the urban situation, infrastructure development \\
\hline & Complex design concept for the renewal - interdisciplinary planning \\
\hline & New functions, recreational green spaces \\
\hline & Creation of jobs \\
\hline & PR and follow-up \\
\hline & New outdoor functions, pedestrian and bike routes, playgrounds or recreation areas \\
\hline \multirow{4}{*}{ Strengthening of local identity } & Local social demand and support for the renewal of the site \\
\hline & Creation of cultural values \\
\hline & Interpretation of local history \\
\hline & Temporary utilization and participatory planning \\
\hline \multirow{6}{*}{ Improvement of livelihoods } & Creation of jobs \\
\hline & Economic strength - use of internal resources \\
\hline & Creation of cultural values \\
\hline & Complex design concept for the renewal - interdisciplinary planning \\
\hline & Plantation, revegetation of the sites, increase the proportion of green areas \\
\hline & New outdoor functions, pedestrian and bike routes, playgrounds or recreation areas \\
\hline \multicolumn{2}{|l|}{$\begin{array}{l}\text { Environmental } \\
\text { appreciation }\end{array}$} \\
\hline \multirow{3}{*}{ Environmental remediation } & Elimination of pollution \\
\hline & Renewal of buildings \\
\hline & Plantation, revegetation of the sites, increase the proportion of green areas \\
\hline \multirow{4}{*}{ Sustainability } & Utilization of natural features, efforts to increase sustainability \\
\hline & Complex design concept for the renewal - interdisciplinary planning \\
\hline & Temporary utilization and participatory planning \\
\hline & Pre-planning the effects on urban structure and ecology \\
\hline \multirow{3}{*}{$\begin{array}{l}\text { New ecological and } \\
\text { recreational values }\end{array}$} & New functions, recreational green spaces \\
\hline & Plantation, revegetation of the sites, increase the proportion of green areas \\
\hline & New outdoor functions, pedestrian and bike routes, playgrounds or recreation areas \\
\hline
\end{tabular}

Table 2. Design goals and their respective tools

\section{OZD CULTURE FACTORY PROJECT}

Designer: Archinvest '97 Kft., Mixa Stúdió, Sterner Kft., Györgyi Csontos DLA

The brownfield area designated for rehabilitation is located in the enclave-like historical centre of Ózd, the former industrial town in Northern Hungary. The local government is planning to achieve an eco-cultural utilization of the area, using EU funds. The factory was closed in 1990 from one day to the next, resulting in 30\% of the city's population losing their jobs [6] [7]. The rehabilitation itself began in 2014, and is currently underway.

The parts of the project are the following: renovation of the existing City Museum a new outdoor industrial heritage area - public park and walkway; the construction of the educational building and the exhibition area of the National Cultural Digital Archive Centre in the former power plant. The cultural projects will be supplemented with another tourist attraction: the old steam blower house will be used for the storage and interpretation of old Hungarian film rolls, and for filming in the original scenery of traditional Hungarian movies for families and groups of friends.

As a result of the project at least 50 new jobs will be created in the city and the tourism will increase: 100 - 400 visitors per day are expected. [8] [9] 
The special features, relating to the industrial past serve the strengthening of cultural identity: collection of old artefacts of industrial history and displaying them as spatial elements, along with the cleaning of polluted soil and the use native plants during the development of the area. (Figure 4.)
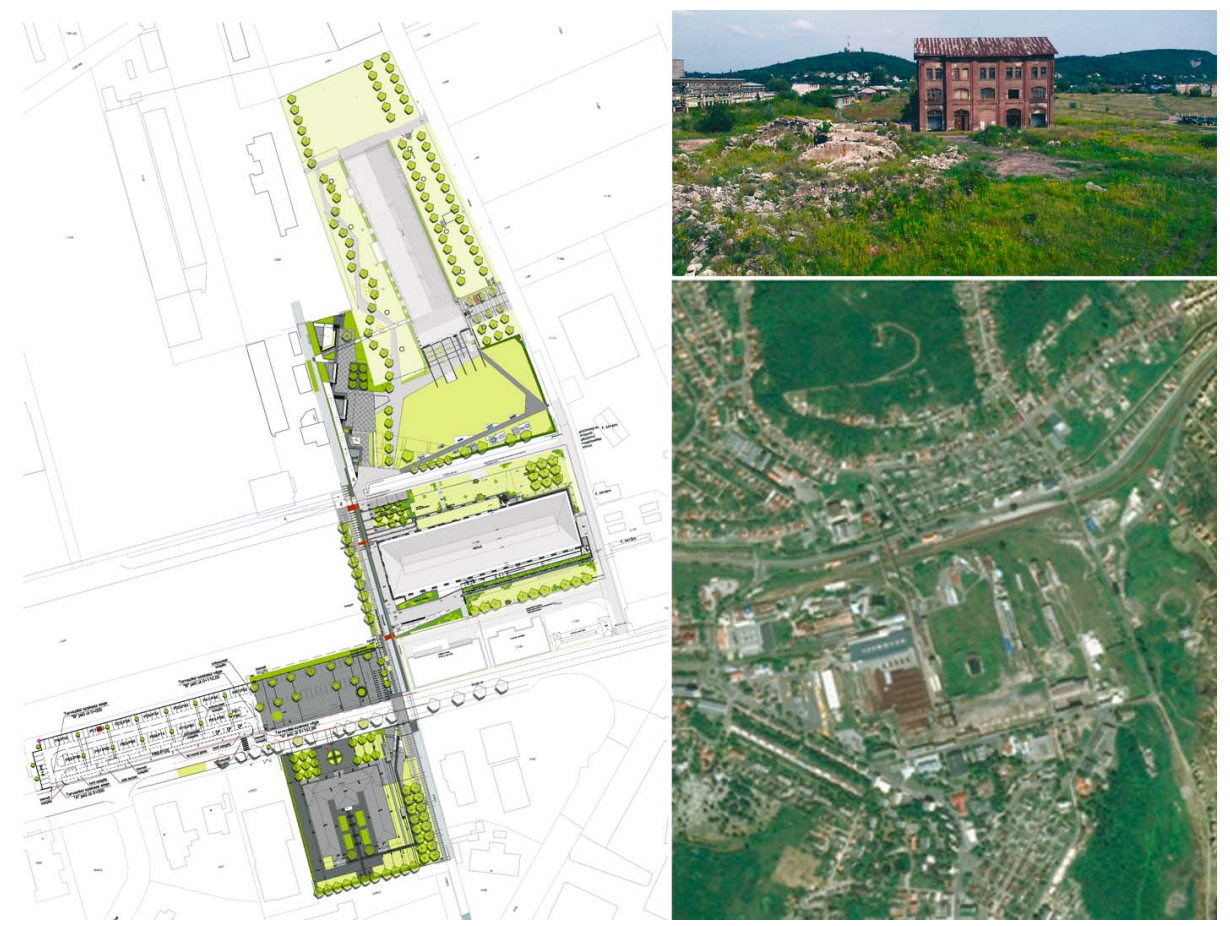

Figure 4. Cultural Factory, Ózd

\section{PROPOSAL AND EVALUATION}

The above mentioned goals and tools can be used when evaluating the possibilities and success of a future rehabilitation. Below, a study of these tools is presented on the example of the Culture Factory project, knowing the goals it is intended to achieve.

\subsection{Points to be strengthened}

- Complex reuse, complete utilisaion - Complex design concept for the renewalinterdisciplinary planning, Changing the urban context by infrastructure development, PR and follow-up,

- Self-sufficiency and generation of income - Complex design concept for the renewal - interdisciplinary planning, creation of jobs, $R$ and follow-up, economic strength - use of internal resources, monitoring,

- Role as engine of economic growth - Economic strength - use of internal resources, Unique and attractive image, Innovation, high-tech buildings, the most advanced technology available or "star architects", External economic catalysts 
- 24-hour use - Changing the urban situation, infrastructure development, Complex design concept for the renewal - interdisciplinary planning, New functions, recreational green spaces, Creation of jobs, PR and follow-up Structural Change City situation, infrastructure development, complex design concept of site renewal - interdisciplinary design, new features, recreational green areas, job creation, public relations and post-production

- Improvement of livelihoods - Creation of jobs, Economic strength - use of internal resources, Creation of cultural values, Complex design concept for the renewal - interdisciplinary planning

- Sustainability - Utilization of natural features, efforts to increase sustainability

\subsection{Assessment}

Some of the tools listed above were implemented in the program in theory. The problem is that such unforeseen economic and foreseeable, but poorly calculated social processes occurred between the adoption and the implementation of the programme that certain parts of the programme have to be reconsidered.

The area, located in an urban environment, is intended to become a touristic attraction of regional importance, and it is expected to boost tourism in the entire region. The constant decline in the proportion of population that is able to pay for such services in the region makes the goals of complete utilization and self-sufficiency even more difficult. The project is not connected to infrastructure development (now it takes is 2.5 hours to reach the site from Budapest by car, 3.5 hours by coach and more than 5 hours by train). Therefore, it is questionable whether the planned attendance can be guaranteed.

The strengthening of ecological and economical sustainability would improve the chance of self-sufficiency as well. The initial Cultural Factory program takes the current situation of the area into consideration only partially. The conceptual principles are not based on the reuse of existing buildings and industrial heritage, the harmonisation of past and future functions. Modern energy management (use of renewable resources by solar panels, heating/cooling using heat pumps and fire water storage based on the high groundwater level) is included in certain project elements in the detailed plans, but the currently implemented parts of the project are not connected to a comprehensive concept of sustainability on local, municipal and regional level. [4]

\section{CONCLUSION}

The international and Hungarian examples for the revitalization of industrial sites show that both temporary utilization and functional change can hold a lot of potential in such areas. After their transformation, these urban areas can once again become an integral part of the cultural and economic life of the city, as well as its green surface system.

The Culture Factory in Ózd has a chance to be an exemplary rehabilitation project, if the experiences from other sites are flexibly adapted, the way landscape and the natural systems can, and a flux is created in the urban landscape. 


\section{REFERENCES:}

[1.] Barta, Györgyi. Rehabilitációs megoldások az európai nagyvárosok barnaövezetében. Budapest : MTA RKK KÉTI, 2004.

[2.] A magyar ipar területi folyamatai, 1945-2000. Barta, Gy. Budapest : Dialóg Campus, 2002.

[3.] Weilacher, U. (ed.). Learning from Duisburg Nord - Kommentare internationaler Experten zu einem Meisterstück aktueller Landschaftsarchitektur - Comments of international experts on amasterpiece of contemporary landscape architecture. München : Techn, Univ. München, Fac. Architectur, 2009.

[4.] Adorján, Anna. Iparterületek revitalizációjának lehetőségei: sikeresség fenntarthatóság és ezek eszközeinek elemzése megvalósult és külföldi példákon. Budapest : Budapesti Müszaki Egyetem Urbanista tanszék, szakdolgozat, 2015.

[5.] Zeisel, J. Inquiry by design - Environment/Behavior/Neuroscience in architecture, interiors, landscape and planning. New York : Norton \& Co., 2006.

[6.] Tanulmányok, állapotrajzok, koncepciók - Ózd (Studies, situation reports, concepts - Ózd). Gábor, Csontos Györgyi - Reichl. Budapest : MÉK, 2003., Városépítészet, tájépítészet 2003. (Urban design, Landscape design 2003.). kötet.

[7.] Csontos, Györgyi. Múemléki értékeink 4. - Ózd (Treasures of the cultural heritage in Hungary 4. - Ózd). Budapest : KÖH, 2005.

[8.] Társulás, Ózdi kistérségi. Rombauer terv - Ózd kistérségének középtávú cselekvési terve . Ózd : ismeretlen szerző, 2011.

[9.] Gábor, Képes. http://mandarchiv.hu. MaNDA Magyar Nemzeti Digitális filmarchívum. [Online] 2014.. 12. 11. [Hivatkozva: 2015.. 06. 23.] http://mandarchiv.hu/cikk/3537/Digitalis_elmenykozpont_lesz_a_romos_csarnokbol.

[10.] A bányászati és kohászati ipari örökség megőrzésének szükségessége és lehetöségei. Horváth, B. Miskolc : ismeretlen szerző, 1999., Északkelet-Magyarország, gazdaság, kultúra, tudomány társadalompolitikai folyóirat 1999. (4. évf.) 11-12- sz. 49-50. kötet.

[11.] Nyaraljon Ruhr-vidéken!: A szénbányászat és vaskohászati ipari örökség megőrzésének szükségességéröl és ehetőségéről. Németh, Gy. Budapest : ismeretlen szerző, 2002.., Újholnap: irodalmi, művészeti, térsadalmi folyóirat 2002. (47. évf.) 3. sz. 140-143.. kötet. ISSN 1219-3259.

[12.] Váczi, P. Az ipari müemlékvédelem helyzete Magyarországon. Budpest : Országos Mủemlékvédelmi Hivatal, 1997.

\section{ONLINE SOURCES:}

- www.wiener-gasometer.at

- $\quad$ www.epiteszforum.hu - Gasometer city 2002, szerző: Vargha Mihály

- $\quad$ http://hu.wikipedia.org/wiki/Millen\%C3\%A1ris

- $\quad$ http://hu.wikipedia.org/wiki/Ruhr-vid\%C3\%A9k

- http://attus.hu/Ujitasok_a_Ruhr-videken.html

- www.landarch.com

\section{ILLUSTRATIONS:}

- $\quad$ Figure 1. Zollverein, Essen, Germany, - http://attus.hu/Ujitasok_a_Ruhr-videken.html, google earth

- $\quad$ Figure 2. Haute-Deûle river Banks - Landezine, 2012. Haute Deûle River Banks - New Sustainable District by Bruel-Delmar,

- $\quad$ Figure 3. Millenáris, Budapest - www.ujirany.com, google earth

- $\quad$ Figure 4. Cultural Factory project, Ózd - authors own plan, authors own photo, google earth 